\begin{tabular}{cl|l}
$\begin{array}{c}\text { Cellular Physiology } \\
\text { and Biochemistry }\end{array}$ & Cell Physiol Biochem 2012;30:428-438 & \multicolumn{2}{l}{ DOI: 10.1159/000339036 } & $\begin{array}{l}\text { O 2012 S. Karger AG, Basel } \\
\text { www.karger.com/cpb }\end{array}$ \\
\cline { 2 - 3 } & $\begin{array}{l}\text { Published online: July 06, 2012 } \\
\text { Accepted: May 14, 2012 }\end{array}$ & $1015-8987 / 12 / 0302-0428 \$ 38.00 / 0$
\end{tabular}

\title{
Induction of Programmed Erythrocyte Death by Gambogic Acid
}

\author{
Adrian Lupescu* Kashif Jilani* Christine Zelenak Mohanad Zbidah Nazneen \\ Shaik Florian Lang
}

Department of Physiology, University of Tuebingen, Tuebingen, *contributed equally and thus share the first authorship

\section{Key Words}

Phosphatidylserine $\bullet$ Gambogic acid $\bullet$ Calcium $\bullet$ Cell volume $•$ Eryptosis

\begin{abstract}
Gambogic acid, a xanthone from Garcinia hanburyi, stimulates apoptosis and has thus anticancer potency. Similar to apoptosis of nucleated cells, erythrocytes may undergo apoptosis-like suicidal death or eryptosis, which is characterized by cell shrinkage and cell membrane scrambling leading to phosphatidylserine-exposure at the cell surface. Eryptosis could be triggered by increase of cytosolic $\mathrm{Ca}^{2+}$-activity $\left(\left[\mathrm{Ca}^{2+}\right]_{\mathrm{i}}\right)$, ceramide formation, ATPdepletion and caspase activation. The present study explored, whether gambogic acid triggers eryptosis of human erythrocytes. $\left[\mathrm{Ca}^{2+}\right]_{i}$ was estimated utilizing Fluo-3 fluorescence, cell volume from forward scatter, phosphatidylserine-exposure from annexin-V-binding, hemolysis from hemoglobin release, ceramide abundance utilizing antibodies, and cytosolic ATP with luciferinluciferase. A $48 \mathrm{~h}$ exposure to gambogic acid $(500 \mathrm{nM})$ significantly increased $\left[\mathrm{Ca}^{2+}\right]_{\mathrm{i}^{\prime}}$ stimulated ceramide formation, decreased forward scatter and increased annexin-V-binding. Gambogic acid exposure was followed by a slight but significant increase of hemolysis. Gambogic acid did not significantly modify cytosolic ATP-concentration. Removal of extracellular $\mathrm{Ca}^{2+}$ slightly, but significantly blunted the effect of gambogic acid (500 nM) on annexin-V-binding. The present observations disclose a novel effect of gambogic acid, i.e. stimulation of suicidal death of human erythrocytes or eryptosis, paralleled by $\mathrm{Ca}^{2+}$-entry, ceramide formation, cell shrinkage and phosphatidylserine-exposure.
\end{abstract}

\section{Introduction}

Copyright $\odot 2012$ S. Karger AG, Basel

Gambogic acid, a xanthone from Garcinia hanburyi, is a nutraceutical with anticancer, anti-HIV-1, antibacterial, anti-inflammatory and neurotrophic activities [1-4]. Its anticancer activity presumably results from its ability to induce apoptosis [4-7]. Gambogic acid induces 


\section{Cellular Physiology Cell Physiol Biochem 2012;30:428-438 \\ \begin{tabular}{ll|l} 
and Biochemistry & $\begin{array}{l}\text { DOI: 10.1159/000339036 } \\
\text { Published online: July 06, } 2012\end{array}$ & $\begin{array}{l}\text { C 2012 S. Karger AG, Basel } \\
\text { www.karger.com/cpb }\end{array}$ \\
\cline { 2 - 3 } Lupescu/Jilani/Zelenak et al.: Gambogic Acid-induced Eryptosis
\end{tabular}}

apoptosis of a wide variety of cells including oral squamous cell carcinoma [8], gastric cancer cells [9-12], cholangiocarcinoma cells [2], hepatoma cells [13, 14], pancreatic cancer cells [15], lung cancer cells [16], breast cancer cells [17], prostate cancer cells [18], glioblastoma cells [19], osteosarcoma cells [20], Jurkat cells [21, 22], K562 cells [23] and A549 cells [24]. Gambogic acid is effective by interfering with the expression of Bax and Bcl-2 proteins [12, $17,25,26]$, inhibition of SRC-3 [23], inactivation of the Akt pathway [23] stimulation of the transferrin receptor $[16,27,28]$, interference with nucleophosmin and nucleoporins [21], interaction with Hsp90 [29], deregulation of NF- $\mathrm{B}$ [29], induction of p21(Waf1/CIP1) expression [30], inhibition of STAT3 phosphorylation [31], inhibition of survivin [11], proteasome inhibition [32], down-regulation of $\mathrm{mdm} 2$ expression [30, 33], reactive oxygen species accumulation [13], interaction with $\mathrm{K}^{+}$channel activity [34], suppression of vascular endothelial growth factor signaling [18], inhibition of angiogenesis [18], and activation of T lymphocytes [35].

Similar to apoptosis of nucleated cells, suicidal erythrocyte death or eryptosis is paralleled by cell membrane scrambling and cell shrinkage [36]. Eryptosis is elicited by $\mathrm{Ca}^{2+}$ entry through $\mathrm{Ca}^{2+}$-permeable cation channels $[37,38]$. The subsequent increase of cytosolic $\mathrm{Ca}^{2+}$ concentration results in activation of $\mathrm{Ca}^{2+}$-sensitive $\mathrm{K}^{+}$channels [39] with $\mathrm{K}^{+}$ exit, hyperpolarization, $\mathrm{Cl}^{-}$exit and thus cellular $\mathrm{KCl}$ loss together with osmotically obliged water, events leading to cell shrinkage [40]. The increased cytosolic $\mathrm{Ca}^{2+}$ concentration is further followed by cell membrane scrambling with phosphatidylserine exposure at the cell surface [41]. The $\mathrm{Ca}^{2+}$ sensitivity of erythrocyte cell membrane scrambling is increased by ceramide, which similarly stimulates eryptosis [42]. Further triggers of eryptosis include energy depletion [43] and activation of caspases [44-48]. Eryptosis is further influenced by AMP activated kinase AMPK [38], cGMP-dependent protein kinase [49] and Janusactivated kinase JAK3 [50].

The present study explored, whether gambogic acid triggers eryptosis and, if so, to elucidate the underlying mechanisms.

\section{Materials and Methods}

\section{Erythrocytes, solutions and chemicals}

Leukocyte-depleted erythrocytes were kindly provided by the blood bank of the University of Tübingen. The study is approved by the ethics committee of the University of Tübingen (184/2003V). Erythrocytes were incubated in vitro at a hematocrit of $0.4 \%$ in Ringer solution containing (in mM) $125 \mathrm{NaCl}, 5 \mathrm{KCl}, 1 \mathrm{MgSO}_{4}$, $32 \mathrm{~N}$-2-hydroxyethylpiperazine-N-2-ethanesulfonic acid (HEPES), 5 glucose, $1 \mathrm{CaCl}_{2}$; pH 7.4 at $37^{\circ} \mathrm{C}$ for 48 $\mathrm{h}$. Where indicated, erythrocytes were exposed to gambogic acid (Enzo, Lörrach, Germany) at the indicated concentrations. In $\mathrm{Ca}^{2+}$-free Ringer solution, $1 \mathrm{mM} \mathrm{CaCl}_{2}$ was substituted by $1 \mathrm{mM} \mathrm{glycol-bis(2-aminoethylether)-}$ $\mathrm{N}, \mathrm{N}, \mathrm{N}^{\prime}, \mathrm{N}^{\prime}$-tetraacetic acid (EGTA).

\section{FACS analysis of annexin-V-binding and forward scatter}

After incubation under the respective experimental condition, $50 \mu \mathrm{l}$ cell suspension were washed in Ringer solution containing $5 \mathrm{mM} \mathrm{CaCl}_{2}$ and then stained with Annexin-V-FITC (1:200 dilution; ImmunoTools, Friesoythe, Germany) in this solution at $37^{\circ} \mathrm{C}$ for $20 \mathrm{~min}$ under protection from light. In the following, the forward scatter (FSC) of the cells was determined, and annexin-V fluorescence intensity was measured in FL-1 with an excitation wavelength of $488 \mathrm{~nm}$ and an emission wavelength of $530 \mathrm{~nm}$ on a FACS Calibur (BD, Heidelberg, Germany).

\section{Confocal microscopy and immunofluorescence}

For the visualization of eryptotic erythrocytes, $4 \mu \mathrm{l}$ of erythrocytes, incubated in the respective experimental solutions, were stained with FITC-conjugated Annexin-V-Fluos (1:100 dilution; ImmunoTools, Friesoythe, Germany) in $200 \mu \mathrm{l}$ Ringer solution containing $5 \mathrm{mM} \mathrm{CaCl}_{2}$. The erythrocytes were washed twice and finally resuspended in $50 \mu \mathrm{l}$ of Ringer solution containing $5 \mathrm{mM} \mathrm{CaCl}_{2}$. The cell suspension (20 $\left.\mu \mathrm{l}\right)$ was mounted with Prolong Gold antifade reagent (Invitrogen, Darmstadt, Germany) onto a glass slide, covered 


\begin{tabular}{|c|c|c|}
\hline $\mathrm{Col}$ & Cell Physiol Biochem 2012;30:428-438 & \\
\hline and Biochemistry & $\begin{array}{l}\text { DOI: 10.1159/000339036 } \\
\text { Published online: July 06, } 2012\end{array}$ & $\begin{array}{l}\text { @ } 2012 \text { S. Karger AG, Basel } \\
\text { www.karger.com/cpb }\end{array}$ \\
\hline
\end{tabular}

with a coverslip and images were subsequently taken on a Zeiss LSM 5 EXCITER confocal laser scanning microscope (Carl Zeiss MicroImaging, Oberkochen, Germany) with a water immersion Plan-Neofluar 63/1.3 NA DIC.

\section{Measurement of intracellular $\mathrm{Ca}^{2+}$}

After incubation-erythrocytes were washed in Ringer solution and then loaded with Fluo-3/AM (Biotium, Hayward, USA) in Ringer solution containing $5 \mathrm{mM} \mathrm{CaCl}_{2}$ and $2 \mu \mathrm{M}$ Fluo-3/AM. The cells were incubated at $37^{\circ} \mathrm{C}$ for $30 \mathrm{~min}$ and washed twice in Ringer solution containing $5 \mathrm{mM} \mathrm{CaCl}{ }_{2}$. The Fluo-3/AMloaded erythrocytes were resuspended in $200 \mu$ Ringer. Then, $\mathrm{Ca}^{2+}$-dependent fluorescence intensity was measured in fluorescence channel FL-1 in FACS analysis.

\section{Determination of intracellular ATP concentration}

For determination of intracellular erythrocyte ATP, $90 \mu \mathrm{l}$ of erythrocyte pellets were incubated for $48 \mathrm{~h}$ at $37^{\circ} \mathrm{C}$ in Ringer solution with or without gambogic acid and in Ringer solution with or without extracellular calcium (final hematocrit 5\%). Additionally, erythrocytes were also incubated in glucose depleted Ringer solution as a positive control. All subsequent manipulations were performed at $4^{\circ} \mathrm{C}$ to avoid ATP degradation. Cells were lysed in distilled water, and proteins were precipitated by addition of $\mathrm{HClO}_{4}$ (5\%). After centrifugation, an aliquot of the supernatant $(400 \mu \mathrm{l})$ was adjusted to $\mathrm{pH} 7.7$ by addition of saturated $\mathrm{KHCO}_{3}$ solution. After dilution of the supernatant, the ATP concentrations of the aliquots were determined utilizing the luciferin-luciferase assay kit (Roche Diagnostics) on a luminometer (Berthold Biolumat LB9500, Bad Wildbad, Germany) according to the manufacturer's protocol. ATP concentrations are expressed in mmol/l cytosol of erythrocytes.

\section{Determination of ceramide formation}

For the determination of ceramide, a monoclonal antibody-based assay was used. After incubation with and without gambogic acid, cells were stained for $1 \mathrm{~h}$ at $37^{\circ} \mathrm{C}$ with $1 \mu \mathrm{g} / \mathrm{ml}$ anti-ceramide antibody (clone MID 15B4, Alexis, Grünberg, Germany) in PBS containing 0.1\% bovine serum albumin (BSA) at a dilution of 1:5. The samples were washed twice with PBS-BSA. Subsequently, the cells were stained for 30 minutes with polyclonal fluorescein-isothiocyanate (FITC)-conjugated goat anti-mouse IgG and IgM specific antibody (Pharmingen, Hamburg, Germany) diluted 1:50 in PBS-BSA. Unbound secondary antibody was removed by repeated washing with PBS-BSA. The samples were then analyzed by flow cytometric analysis in FL-1.

\section{Measurement of hemolysis}

For the determination of hemolysis the samples were centrifuged ( $3 \mathrm{~min}$ at $400 \mathrm{~g}$, room temperature) after incubation, and the supernatants were harvested. As a measure of hemolysis, the hemoglobin ( $\mathrm{Hb}$ ) concentration of the supernatant was determined photometrically at $405 \mathrm{~nm}$. The absorption of the supernatant of erythrocytes lysed in distilled water was defined as $100 \%$ hemolysis.

\section{Statistics}

Data are expressed as arithmetic means \pm SEM. As indicated in the figure legends, statistical analysis was made using ANOVA with Tukey's test as post-test and $t$ test as appropriate. $\mathrm{n}$ denotes the number of different erythrocyte specimens studied. Since different erythrocyte specimens used in distinct experiments are differently susceptible to triggers of eryptosis, the same erythrocyte specimens have been used for control and experimental conditions.

\section{Results}

In order to estimate cytosolic $\mathrm{Ca}^{2+}$ activity in erythrocytes, the erythrocytes were loaded with Fluo-3 and the Fluo-3 fluorescence determined in FACS analysis. As illustrated in Fig. 1, treatment of human erythrocytes with gambogic acid resulted in an increase of Fluo-3 fluorescence. The effect reached statistical significance at $500 \mathrm{nM}$ gambogic acid concentrations. Thus, gambogic acid increased cytosolic $\mathrm{Ca}^{2+}$ concentration.

An increase of cytosolic $\mathrm{Ca}^{2+}$ concentration is known to trigger erythrocyte shrinkage by activation of $\mathrm{Ca}^{2+}$-sensitive $\mathrm{K}^{+}$channels with subsequent exit of $\mathrm{KCl}$ paralleled by osmotically 


\section{Cellular Physiology and Biochemistry}

\begin{tabular}{|c|c|}
\hline Cell Physiol Biochem 201 & \\
\hline $\begin{array}{l}\text { DOI: } 10.1159 / 000339036 \\
\text { Published online: July 06, } 2012\end{array}$ & $\begin{array}{l}\text { (c) } 2012 \text { S. Karger AG, Basel } \\
\text { www.karger.com/cpb }\end{array}$ \\
\hline
\end{tabular}

Fig. 1. Effect of gambogic acid on erythrocyte cytosolic $\mathrm{Ca}^{2+}$ concentration. A. Original histogram of Fluo-3 fluorescence in erythrocytes following exposure for $48 \mathrm{~h}$ to Ringer solution without $(-$, black line $)$ and with $(+$, red line $)$ presence of $500 \mathrm{nM}$ gambogic acid. B. Arithmetic means \pm SEM $(\mathrm{n}=$ 10) of the normalized geo means
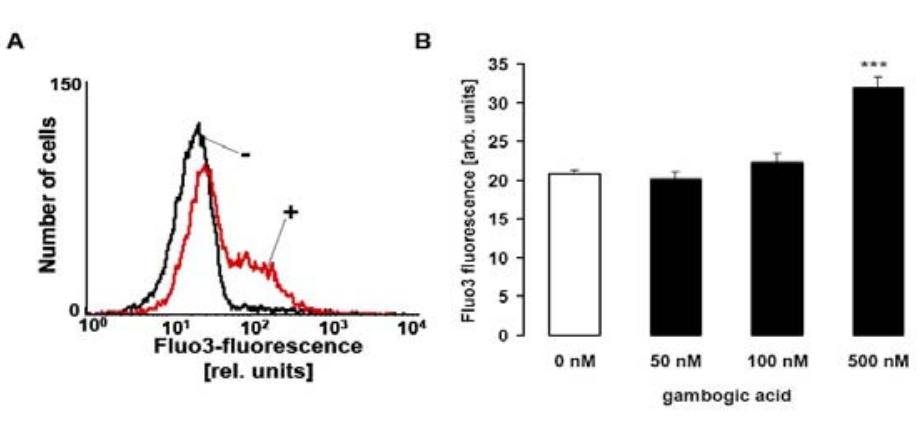
(geometric mean of the histogram in arbitrary units) of Fluo-3 fluorescence in erythrocytes exposed for $48 \mathrm{~h}$ to Ringer solution without (white bar) or with (black bars) gambogic acid $(50-500 \mathrm{nM}) .^{* * *}(\mathrm{p}<0.001)$ indicates significant difference from the absence of gambogic acid (ANOVA).

Fig. 2. Effect of gambogic acid on erythrocyte forward scatter. A. Original histogram of forward scatter of erythrocytes following exposure for $48 \mathrm{~h}$ to Ringer solution without $(-$, black line $)$ and with $(+$, red line) presence of 500 nM gambogic acid. B. Arithmetic means \pm SEM $(n=10)$ of the normalized erythrocyte forward

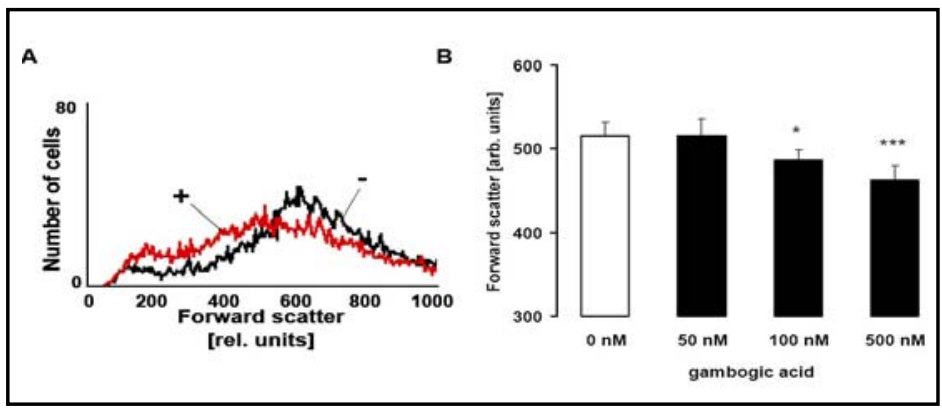
scatter (FSC) following incubation for $48 \mathrm{~h}$ to Ringer solution without (white bar) or with (black bars) gambogic acid $(50-500 \mathrm{nM}) . *{ }^{* * *}(\mathrm{p}<0.05, \mathrm{p}<0.001)$ indicates significant difference from the absence of gambogic acid (ANOVA).

Fig. 3. Effect of gambogic acid on phosphatidylserine exposure and hemolysis. A. Original histogram of annexin-V binding of erythrocytes following exposure for $48 \mathrm{~h}$ to Ringer solution without (-, black line) and with $(+$, red line) presence of $500 \mathrm{nM}$ gambogic acid. B. Arithmetic means \pm SEM of erythrocyte annexin-V-binding ( $\mathrm{n}=10$ ) following incubation for

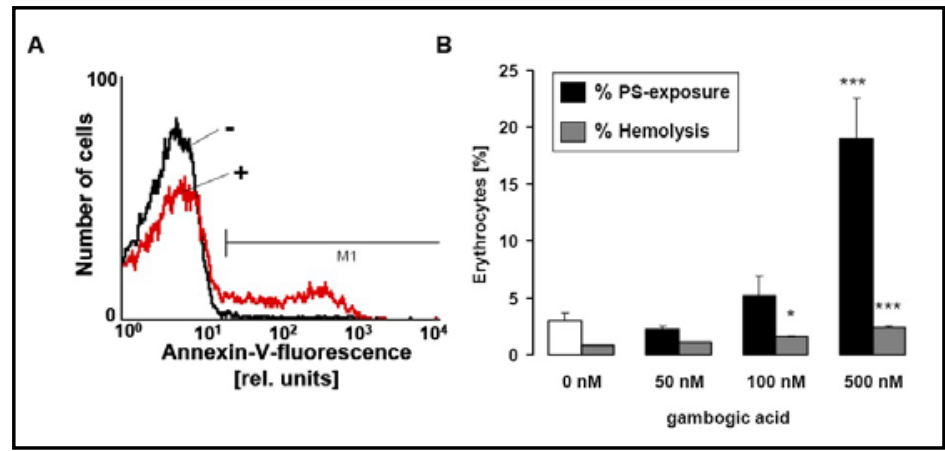
$48 \mathrm{~h}$ to Ringer solution without (white bar) or with (black bars) presence of gambogic acid (50-500 $\mathrm{nM}$ ). For comparison, arithmetic means \pm SEM $(n=4)$ of the percentage of hemolysis is shown as grey bars. * $(\mathrm{p}<0.05),{ }^{* * *}(\mathrm{p}<0.001)$ indicates significant difference from the absence of gambogic acid (ANOVA).

obliged water. To test, whether gambogic acid exposure indeed leads to cell shrinkage, cell volume was estimated utilizing forward scatter in FACS analysis. As shown in Fig. 2, gambogic acid treatment decreased forward scatter, an effect statistically significant at 100 nM gambogic acid.

An increase of cytosolic $\mathrm{Ca}^{2+}$ activity is further known to trigger cell membrane scrambling with phosphatidylserine exposure at the cell surface. In order to test whether gambogic acid treatment is indeed followed by cell membrane scrambling, phosphatidylserine exposing erythrocytes were identified utilizing annexin-V-binding, as determined by FACS analysis. As illustrated in Fig. 3, a $48 \mathrm{~h}$ exposure to gambogic acid increased the percentage of annexin- 


\section{Cellular Physiology \\ Cell Physiol Biochem 2012;30:428-438 \\ and Biochemistry

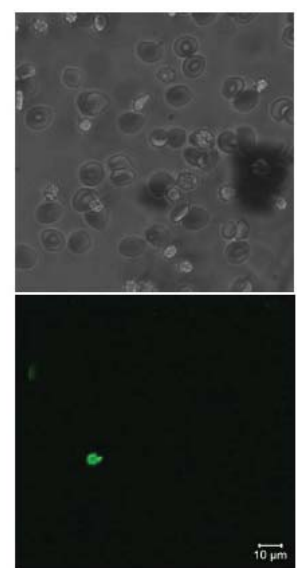

$0 \mathrm{nM}$

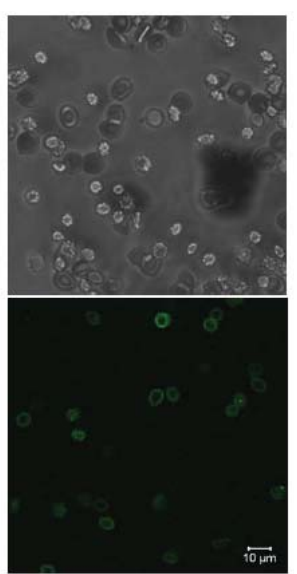

$500 \mathrm{nM}$ gambogic acid gambogic acid

Fig. 4. Phosphatidylserine exposing erythrocytes following gambogic acid exposure. Confocal microscopy of light microscopy (upper panels) and FITC-dependent fluorescence (lower panels) of human erythrocytes stained with FITC-conjugated Annexin-VFluos following 48 hours incubation in Ringer solution without (left panels) and with (right panels) $500 \mathrm{nM}$ gambogic acid.

Fig. 6. Effect of gambogic acid on erythrocyte cytosolic ATP content. Arithmetic means \pm SEM ( $\mathrm{n}=4$ ) of the ATP concentration after a $48 \mathrm{~h}$ incubation in Ringer solution without (white bar) or with (black bar) $500 \mathrm{nM}$ gambogic acid, or in glucose-depleted Ringer solution (grey bar, minus glucose). ${ }^{* * *}(\mathrm{p}<0.001)$ indicates significant difference from control (absence of gambogic acid and presence of glucose) (ANOVA).

V-binding erythrocytes, an effect reaching statistical significance at $500 \mathrm{nM}$ gambogic acid. The effect of gambogic acid on annexin-V-binding was confirmed by confocal microscopy (Fig. 4).

Further experiments explored whether gambogic acid triggered hemolysis, which was estimated from hemoglobin release into the supernatant. As shown in Fig. 3, exposure of erythrocytes for $48 \mathrm{~h}$ to gambogic acid indeed increased the hemoglobin concentration in the supernatant, an effect reaching statistical significance at $100 \mathrm{nM}$ (Fig. 3 B). The percentage of hemolysed erythrocytes was, however, one order of magnitude smaller than the percentage of phosphatidylserine exposing cells.

Another series of experiments explored whether the gambogic acid induced cell membrane scrambling was dependent on $\mathrm{Ca}^{2+}$ entry. To this end, erythrocytes were exposed to $500 \mathrm{nM}$ gambogic acid in the presence or in the nominal absence of extracellular $\mathrm{Ca}^{2+}$. As shown in Fig. 5, the effect of gambogic acid on annexin-V-binding was significantly blunted in the nominal absence of $\mathrm{Ca}^{2+}$. However, even in the nominal absence of $\mathrm{Ca}^{2+}$, gambogic acid still significantly stimulated annexin-V-binding. Accordingly, the stimulation of erythrocyte 


\section{Cellular Physiology and Biochemistry

Fig. 7. Effect of gambogic acid on ceramide formation. A. Original histogram of anti-ceramide FITC-fluorescence in erythro-cytes following exposure for $48 \mathrm{~h}$ to Ringer solution without (-, black line) and with $(+$, red line) presence of 500 $n M$ gambogic acid. B. Arithmetic means \pm SEM $(n=10)$ of ceramide abundance after a $48 \mathrm{~h}$ incubation in Ringer solution without (white bar) or with (black bars) gambogic acid $(500 \mathrm{nM}) . * * *(p<0.001)$ indicates significant difference from control (absence of gambogic acid) ( $t$ test).

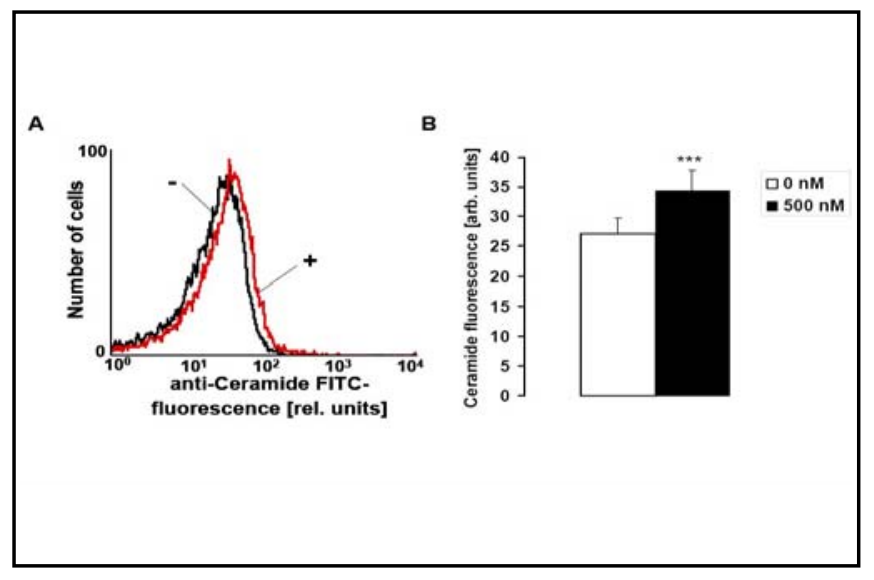

membrane scrambling by gambogic acid must have involved mechanisms in addition to $\mathrm{Ca}^{2+}$ entry.

In order to test whether gambogic acid leads to cellular energy depletion, cytosolic ATP concentration was determined utilizing a luciferin-luciferase assay kit. As shown in Fig. 6, the cytosolic ATP concentration in erythrocytes was not significantly modified by a $48 \mathrm{~h}$ exposure to $500 \mathrm{nM}$ gambogic acid. As a positive control, erythrocytes were incubated in glucose-free Ringer, which significantly decreased cytosolic ATP concentration (Fig. 6). Thus, in contrast to glucose depletion gambogic acid exposure was not followed by a decline of intracellular ATP.

An additional series of experiments explored the effect of gambogic acid treatment on the formation of ceramide. Ceramide abundance was determined utilizing FITC-labeled anticeramide antibodies. As illustrated in Fig. 7, gambogic acid significantly increased ceramidedependent fluorescence.

\section{Discussion}

The present observations reveal that gambogic acid triggers eryptosis, the suicidal death of erythrocytes. Specifically, gambogic acid exposure elicits erythrocyte membrane scrambling and leads to erythrocyte shrinkage. The concentration required for the effect on cell membrane scrambling is in the range of the concentrations effective against tumor growth in vivo, which has been observed at in vivo dosages of $4 \mathrm{mg} / \mathrm{kg}(6 \mu \mathrm{mol} / \mathrm{kg})$ and $8 \mathrm{mg} / \mathrm{kg}(13 \mu \mathrm{mol} / \mathrm{kg})$ [51].

Gambogic acid increases cytosolic $\mathrm{Ca}^{2+}$ activity, an effect presumably due to activation of non-selective cation channels. The molecular identity of the $\mathrm{Ca}^{2+}$ permeable erythrocyte cation channels is still incompletely understood but involves TRPC6 [37]. The cation channels have previously been shown to be activated by oxidative stress [52].

The increase of cytosolic $\mathrm{Ca}^{2+}$ activity is expected to activate $\mathrm{Ca}^{2+}$ - sensitive $\mathrm{K}^{+}$channels $[39,53]$ with subsequent exit of $\mathrm{K}^{+}$following its chemical gradient, cell membrane hyperpolarisation, $\mathrm{Cl}^{-}$exit and thus cellular loss of $\mathrm{KCl}$ with osmotically obliged water [40]. Accordingly, the increase of cytosolic $\mathrm{Ca}^{2+}$ activity following gambogic acid treatment is expected to trigger cell shrinkage, which, according to forward scatter, was indeed a concequence of gambogic acid treatment.

As shown previously $[41,54,55]$, an increase of cytosolic $\mathrm{Ca}^{2+}$ activity further stimulates cell membrane scrambling leading to phosphatidylserine exposure at the erythrocyte surface. The nominal absence of extracellular $\mathrm{Ca}^{2+}$ significantly blunted, but did not fully abrogate the scrambling effect of gambogic acid, indicating that gambogic acid must induce cell membrane scrambling by some additional mechanism(s). Gambogic acid obviously did not induce energy depletion, a known trigger of eryptosis [43]. 


\section{Cellular Physiology Cell Physiol Biochem 2012;30:428-438 \\ \begin{tabular}{ll|l} 
and Biochemistry & $\begin{array}{l}\text { DOI: 10.1159/000339036 } \\
\text { Published online: July 06, } 2012\end{array}$ & $\begin{array}{l}\text { C 2012 S. Karger AG, Basel } \\
\text { www.karger.com/cpb }\end{array}$ \\
\cline { 2 - 3 } Lupescu/Jilani/Zelenak et al.: Gambogic Acid-induced Eryptosis
\end{tabular}}

Gambogic acid did, however, increase the formation of ceramide, which has previously been shown to stimulate cell membrane scrambling in erythrocytes $[42,56]$. Moreover, ceramide may trigger apoptosis of nucleated cells [57]. Excessive ceramide formation contributes to the pathophysiology of several clinical disorders including lung inflammation, fibrosis and infection [58], cystic fibrosis [59], cardiovascular disease [60, 61], Wilson's disease [62], multiple sclerosis [63], major depression [57], Parkinson's disease [64], Alzheimer's disease [57, 65, 66] and diabetes [67-69].

Eryptosis is triggered by a wide variety of xenobiotics [44, 50, 70-72, 72-79] and participates in the pathophysiology of diverse clinical disorders [36], such as diabetes [48, 80, 81], renal insufficiency [82], hemolytic uremic syndrome [83], sepsis [84], sickle cell disease [85]. malaria [62, 86-89], Wilson's disease [62], iron deficiency [90], phosphate depletion [91] and presumably metabolic syndrome [92].

Phosphatidylserine exposing erythrocytes adhere to endothelial CXCL16/SR-PSO [93]. The adhesion of phosphatidylserine exposing erythrocytes to the vascular wall may impair microcirculation [93-98]. Phosphatidylserine exposing erythrocytes further stimulate blood clotting $[94,99,100]$. Thus, excessive eryptosis may foster thrombosis. Moreover, the clearance of phosphatidylserine exposing erythrocytes from circulating blood may lead to anemia [36].

In conclusion, gambogic acid fosters $\mathrm{Ca}^{2+}$ entry and ceramide formation, effects triggering cell membrane scrambling and cell shrinkage, hallmarks of eryptosis. Thus, similar to its effect on nucleated cells, gambogic acid stimulates the suicidal death of erythrocytes.

\section{Acknowledgements}

The authors acknowledge the meticulous preparation of the manuscript by S. Rübe. The authors acknowledge the technical support by Luisa Rosaclerio and Paola M. Tripodi. This study was supported by the Deutsche Forschungsgemeinschaft.

\section{References}

1 Anantachoke N, Tuchinda P, Kuhakarn C, Pohmakotr M, Reutrakul V: Prenylated caged xanthones: Chemistry and biology. Pharm Biol 2012;50:78-91.

2 Hahnvajanawong C, Boonyanugomol W, Nasomyon T, Loilome W, Namwat N, Anantachoke N, Tassaneeyakul W, Sripa B, Namwat W, Reutrakul V: Apoptotic activity of caged xanthones from Garcinia hanburyi in cholangiocarcinoma cell lines. World J Gastroenterol 2010;16:2235-2243.

3 Ren Y, Yuan C, Chai HB, Ding Y, Li XC, Ferreira D, Kinghorn AD: Absolute configuration of (-)-gambogic acid, an antitumor agent. J Nat Prod 2011;74:460-463.

4 Sung B, Prasad S, Yadav VR, Aggarwal BB: Cancer Cell Signaling Pathways Targeted by Spice-Derived Nutraceuticals. Nutr Cancer 2011;

5 Kuemmerle J, Jiang S, Tseng B, Kasibhatla S, Drewe J, Cai SX: Synthesis of caged 2,3,3a,7a-tetrahydro-3,6methanobenzofuran-7(6H)-ones: Evaluating the minimum structure for apoptosis induction by gambogic acid. Bioorg Med Chem 2008;16:4233-4241.

6 Xie H, Qin YX, Zhou YL, Tong LJ, Lin LP, Geng MY, Duan WH, Ding J: GA3, a new gambogic acid derivative, exhibits potent antitumor activities in vitro via apoptosis-involved mechanisms. Acta Pharmacol Sin 2009;30:346354.

7 Zhang HZ, Kasibhatla S, Wang Y, Herich J, Guastella J, Tseng B, Drewe J, Cai SX: Discovery, characterization and SAR of gambogic acid as a potent apoptosis inducer by a HTS assay. Bioorg Med Chem 2004;12:309-317.

8 He D, Xu Q Yan M, Zhang P, Zhou X, Zhang Z, Duan W, Zhong L, Ye D, Chen W: The NF-kappa B inhibitor, celastrol, could enhance the anti-cancer effect of gambogic acid on oral squamous cell carcinoma. BMC Cancer 2009;9:343.

9 Liu LZ, Fang J, Zhou Q Hu X, Shi X, Jiang BH: Apigenin inhibits expression of vascular endothelial growth factor and angiogenesis in human lung cancer cells: implication of chemoprevention of lung cancer. Mol Pharmacol 2005;68:635-643. 


\section{Cellular Physiology and Biochemistry

\begin{tabular}{l|l}
\hline Cell Physiol Biochem 2012;30:428-438 \\
\hline \begin{tabular}{l|l} 
DOI: 10.1159/000339036 & (0) 2012 S. Karger AG, Basel \\
www.karger.com/cpb
\end{tabular} \\
\hline
\end{tabular} \\ Lupescu/Jilani/Zelenak et al.: Gambogic Acid-induced Eryptosis}

10 Wang J, Liu W, Zhao Q, Qi Q Lu N, Yang Y, Nei FF, Rong JJ, You QD, Guo QL: Synergistic effect of 5-fluorouracil with gambogic acid on BGC-823 human gastric carcinoma. Toxicology 2009;256:135-140.

11 Wang T, Wei J, Qian X, Ding Y, Yu L, Liu B: Gambogic acid, a potent inhibitor of survivin, reverses docetaxel resistance in gastric cancer cells. Cancer Lett 2008;262:214-222.

12 Zhao L, Guo QL, You QD, Wu ZQ, Gu HY: Gambogic acid induces apoptosis and regulates expressions of Bax and Bcl-2 protein in human gastric carcinoma MGC-803 cells. Biol Pharm Bull 2004;27:998-1003.

13 Nie F, Zhang X, Qi Q, Yang L, Yang Y, Liu W, Lu N, Wu Z, You Q, Guo Q: Reactive oxygen species accumulation contributes to gambogic acid-induced apoptosis in human hepatoma SMMC-7721 cells. Toxicology 2009;260:60-67.

14 Yang Y, Yang L, You QD, Nie FF, Gu HY, Zhao L, Wang XT, Guo QL: Differential apoptotic induction of gambogic acid, a novel anticancer natural product, on hepatoma cells and normal hepatocytes. Cancer Lett 2007;256:259266.

15 Wang C, Zhang H, Chen B, Yin H, Wang W: Study of the enhanced anticancer efficacy of gambogic acid on Capan-1 pancreatic cancer cells when mediated via magnetic Fe3O4 nanoparticles. Int J Nanomedicine 2011;6:1929-1935.

16 Zhu X, Zhang H, Lin Y, Chen P, Min J, Wang Z, Xiao W, Chen B: Mechanisms of gambogic acid-induced apoptosis in non-small cell lung cancer cells in relation to transferrin receptors. J Chemother 2009;21:666-672.

17 Gu H, Rao S, Zhao J, Wang J, Mu R, Rong J, Tao L, Qi Q, You Q, Guo Q: Gambogic acid reduced bcl-2 expression via p53 in human breast MCF-7 cancer cells. J Cancer Res Clin Oncol 2009;135:1777-1782.

18 Yi T, YiZ, Cho SG, Luo J, Pandey MK, Aggarwal BB, Liu M: Gambogic acid inhibits angiogenesis and prostate tumor growth by suppressing vascular endothelial growth factor receptor 2 signaling. Cancer Res 2008;68:18431850.

19 Qiang L, Yang Y, You QD, Ma YJ, Yang L, Nie FF, Gu HY, Zhao L, Lu N, Qi Q, Liu W, Wang XT, Guo QL: Inhibition of glioblastoma growth and angiogenesis by gambogic acid: an in vitro and in vivo study. Biochem Pharmacol 2008;75:1083-1092.

20 Zhao W, Zhou SF, Zhang ZP, Xu GP, Li XB, Yan JL: Gambogic acid inhibits the growth of osteosarcoma cells in vitro by inducing apoptosis and cell cycle arrest. Oncol Rep 2011;25:1289-1295.

21 Shu W, Chen Y, Li R, Wu Q Cui G, Ke W, Chen Z: Involvement of regulations of nucleophosmin and nucleoporins in gambogic acid-induced apoptosis in Jurkat cells. Basic Clin Pharmacol Toxicol 2008;103:530-537.

22 Wang Y, Chen Y, Chen Z, Wu Q, Ke WJ, Wu QL: Gambogic acid induces death inducer-obliterator 1-mediated apoptosis in Jurkat T cells. Acta Pharmacol Sin 2008;29:349-354.

23 Li R, Chen Y, Zeng LL, Shu WX, Zhao F, Wen L, Liu Y: Gambogic acid induces G0/G1 arrest and apoptosis involving inhibition of SRC-3 and inactivation of Akt pathway in K562 leukemia cells. Toxicology 2009;262:98105.

24 Li Q, Cheng H, Zhu G, Yang L, Zhou A, Wang X, Fang N, Xia L, Su J, Wang M, Peng D, Xu Q: Gambogenic acid inhibits proliferation of A549 cells through apoptosis-inducing and cell cycle arresting. Biol Pharm Bull 2010;33:415-420

25 Xu X, Liu Y, Wang L, He J, Zhang H, Chen X, Li Y, Yang J, Tao J: Gambogic acid induces apoptosis by regulating the expression of Bax and Bcl-2 and enhancing caspase-3 activity in human malignant melanoma A375 cells. Int J Dermatol 2009;48:186-192.

26 Zhai D, Jin C, Shiau CW, Kitada S, Satterthwait AC, Reed JC: Gambogic acid is an antagonist of antiapoptotic Bcl-2 family proteins. Mol Cancer Ther 2008;7:1639-1646.

27 Kasibhatla S, Jessen KA, Maliartchouk S, Wang JY, English NM, Drewe J, Qiu L, Archer SP, Ponce AE, Sirisoma N, Jiang S, Zhang HZ, Gehlsen KR, Cai SX, Green DR, Tseng B: A role for transferrin receptor in triggering apoptosis when targeted with gambogic acid. Proc Natl Acad Sci U S A 2005;102:12095-12100.

28 Pandey MK, Sung B, Ahn KS, Kunnumakkara AB, Chaturvedi MM, Aggarwal BB: Gambogic acid, a novel ligand for transferrin receptor, potentiates TNF-induced apoptosis through modulation of the nuclear factor-kappaB signaling pathway. Blood 2007;110:3517-3525.

29 Zhang L, Yi Y, Chen J, Sun Y, Guo Q, Zheng Z, Song S: Gambogic acid inhibits Hsp90 and deregulates TNF-alpha/ NF-kappaB in HeLa cells. Biochem Biophys Res Commun 2010;403:282-287.

30 Rong JJ, Hu R, Qi Q Gu HY, Zhao Q Wang J, Mu R, You QD, Guo QL: Gambogic acid down-regulates MDM2 oncogene and induces p21(Waf1/CIP1) expression independent of p53. Cancer Lett 2009;284:102-112.

31 Prasad S, Pandey MK, Yadav VR, Aggarwal BB: Gambogic acid inhibits STAT3 phosphorylation through activation of protein tyrosine phosphatase SHP-1: potential role in proliferation and apoptosis. Cancer Prev Res (Phila) 2011;4:1084-1094.

32 Huang H, Chen D, Li S, Li X, Liu N, Lu X, Liu S, Zhao K, Zhao C, Guo H, Yang C, Zhou P, Dong X, Zhang C, Guanmei, Dou QP, Liu J: Gambogic acid enhances proteasome inhibitor-induced anticancer activity. Cancer Lett 2011;301:221-228. 
33 Gu H, Wang X, Rao S, Wang J, Zhao J, Ren FL, Mu R, Yang Y, Qi Q Liu W, Lu N, Ling H, You Q, Guo Q: Gambogic acid mediates apoptosis as a p53 inducer through down-regulation of $\mathrm{mdm} 2$ in wild-type p53-expressing cancer cells. Mol Cancer Ther 2008;7:3298-3305.

34 Cui G, Shu W, Wu Q, Chen Y: Effect of Gambogic acid on the regulation of hERG channel in K562 cells in vitro. J Huazhong Univ Sci Technolog Med Sci 2009;29:540-545.

35 Gu H, You Q, Liu W, Yang Y, Zhao L, Qi Q, Zhao J, Wang J, Lu N, Ling H, Guo Q Wang X: Gambogic acid induced tumor cell apoptosis by T lymphocyte activation in $\mathrm{H} 22$ transplanted mice. Int Immunopharmacol 2008;8:1493-1502.

36 Lang F, Gulbins E, Lerche H, Huber SM, Kempe DS, Foller M: Eryptosis, a window to systemic disease. Cell Physiol Biochem 2008;22:373-380.

37 Foller M, Kasinathan RS, Koka S, Lang C, Shumilina E, Birnbaumer L, Lang F, Huber SM: TRPC6 contributes to the $\mathrm{Ca}(2+)$ leak of human erythrocytes. Cell Physiol Biochem 2008;21:183-192.

38 Foller M, Sopjani M, Koka S, Gu S, Mahmud H, Wang K, Floride E, Schleicher E, Schulz E, Munzel T, Lang F: Regulation of erythrocyte survival by AMP-activated protein kinase. FASEB J 2009;23:1072-1080.

39 Brugnara C, de Franceschi L, Alper SL: Inhibition of $\mathrm{Ca}(2+)$-dependent $\mathrm{K}+$ transport and cell dehydration in sickle erythrocytes by clotrimazole and other imidazole derivatives. J Clin Invest 1993;92:520-526.

40 Lang PA, Kaiser S, Myssina S, Wieder T, Lang F, Huber SM: Role of Ca2+-activated K+ channels in human erythrocyte apoptosis. Am J Physiol Cell Physiol 2003;285:C1553-C1560.

41 Berg CP, Engels IH, Rothbart A, Lauber K, Renz A, Schlosser SF, Schulze-Osthoff K, Wesselborg S: Human mature red blood cells express caspase- 3 and caspase-8, but are devoid of mitochondrial regulators of apoptosis. Cell Death Differ 2001;8:1197-1206.

42 Lang F, Gulbins E, Lang PA, Zappulla D, Foller M: Ceramide in suicidal death of erythrocytes. Cell Physiol Biochem 2010;26:21-28.

43 Klarl BA, Lang PA, Kempe DS, Niemoeller OM, Akel A, Sobiesiak M, Eisele K, Podolski M, Huber SM, Wieder T, Lang F: Protein kinase C mediates erythrocyte "programmed cell death" following glucose depletion. Am J Physiol Cell Physiol 2006;290:C244-C253.

44 Bhavsar SK, Bobbala D, Xuan NT, Foller M, Lang F: Stimulation of suicidal erythrocyte death by alpha-lipoic acid. Cell Physiol Biochem 2010;26:859-868.

45 Foller M, Huber SM, Lang F: Erythrocyte programmed cell death. IUBMB Life 2008;60:661-668.

46 Foller M, Mahmud H, Gu S, Wang K, Floride E, Kucherenko Y, Luik S, Laufer S, Lang F: Participation of leukotriene $\mathrm{C}(4)$ in the regulation of suicidal erythrocyte death. J Physiol Pharmacol 2009;60:135-143.

47 Lau IP, Chen H, Wang J, Ong HC, Leung KC, Ho HP, Kong SK: In vitro effect of CTAB- and PEG-coated gold nanorods on the induction of eryptosis/erythroptosis in human erythrocytes. Nanotoxicology 2011;

48 Maellaro E, Leoncini S, Moretti D, Del Bello B, Tanganelli I, De Felice C, Ciccoli L: Erythrocyte caspase-3 activation and oxidative imbalance in erythrocytes and in plasma of type 2 diabetic patients. Acta Diabetol 2011;

49 Foller M, Feil S, Ghoreschi K, Koka S, Gerling A, Thunemann M, Hofmann F, Schuler B, Vogel J, Pichler B, Kasinathan RS, Nicolay JP, Huber SM, Lang F, Feil R: Anemia and splenomegaly in cGKI-deficient mice. Proc Natl Acad Sci U S A 2008;105:6771-6776.

50 Bhavsar SK, Gu S, Bobbala D, Lang F: Janus kinase 3 is expressed in erythrocytes, phosphorylated upon energy depletion and involved in the regulation of suicidal erythrocyte death. Cell Physiol Biochem 2011;27:547556.

51 Hao K, Liu XQ Wang GJ, Zhao XP: Pharmacokinetics, tissue distribution and excretion of gambogic acid in rats. Eur J Drug Metab Pharmacokinet 2007;32:63-68.

52 Brand VB, Sandu CD, Duranton C, Tanneur V, Lang KS, Huber SM, Lang F: Dependence of Plasmodium falciparum in vitro growth on the cation permeability of the human host erythrocyte. Cell Physiol Biochem 2003;13:347-356.

53 Bookchin RM, Ortiz OE, Lew VL: Activation of calcium-dependent potassium channels in deoxygenated sickled red cells. Prog Clin Biol Res 1987;240:193-200.

54 Bratosin D, Estaquier J, Petit F, Arnoult D, Quatannens B, Tissier JP, Slomianny C, Sartiaux C, Alonso C, Huart JJ, Montreuil J, Ameisen JC: Programmed cell death in mature erythrocytes: a model for investigating death effector pathways operating in the absence of mitochondria. Cell Death Differ 2001;8:1143-1156.

55 Lang KS, Duranton C, Poehlmann H, Myssina S, Bauer C, Lang F, Wieder T, Huber SM: Cation channels trigger apoptotic death of erythrocytes. Cell Death Differ 2003;10:249-256.

56 Lang KS, Myssina S, Brand V, Sandu C, Lang PA, Berchtold S, Huber SM, Lang F, Wieder T: Involvement of ceramide in hyperosmotic shock-induced death of erythrocytes. Cell Death Differ 2004;11:231-243.

57 Kornhuber J, Tripal P, Reichel M, Muhle C, Rhein C, Muehlbacher M, Groemer TW, Gulbins E: Functional Inhibitors of Acid Sphingomyelinase (FIASMAs): a novel pharmacological group of drugs with broad clinical applications. Cell Physiol Biochem 2010;26:9-20. 


\section{Cellular Physiology Cell Physiol Biochem 2012;30:428-438 \begin{tabular}{ll} 
and BiOChemistry Published online: July 06, 2012 & $\begin{array}{l}\text { C } 2012 \text { S. Karger AG, Basel } \\
\text { www.karger.com/cpb }\end{array}$ \\
\hline
\end{tabular}}

58 Dhami R, He X, Schuchman EH: Acid sphingomyelinase deficiency attenuates bleomycin-induced lung inflammation and fibrosis in mice. Cell Physiol Biochem 2010;26:749-760.

59 Becker KA, Grassme H, Zhang Y, Gulbins E: Ceramide in Pseudomonas aeruginosa infections and cystic fibrosis. Cell Physiol Biochem 2010;26:57-66.

60 Kuebler WM, Yang Y, Samapati R, Uhlig S: Vascular barrier regulation by PAF, ceramide, caveolae, and NO - an intricate signaling network with discrepant effects in the pulmonary and systemic vasculature. Cell Physiol Biochem 2010;26:29-40.

61 Li X, Becker KA, Zhang Y: Ceramide in redox signaling and cardiovascular diseases. Cell Physiol Biochem 2010;26:41-48.

62 Lang PA, Schenck M, Nicolay JP, Becker JU, Kempe DS, Lupescu A, Koka S, Eisele K, Klarl BA, Rubben H, Schmid KW, Mann K, Hildenbrand S, Hefter H, Huber SM, Wieder T, Erhardt A, Haussinger D, Gulbins E, Lang F: Liver cell death and anemia in Wilson disease involve acid sphingomyelinase and ceramide. Nat Med 2007;13:164170.

63 Walter S, Fassbender K: Spingolipids in Multiple Sclerosis. Cell Physiol Biochem 2010;26:49-56.

64 Arboleda G, Huang TJ, Waters C, Verkhratsky A, Fernyhough P, Gibson RM: Insulin-like growth factor-1dependent maintenance of neuronal metabolism through the phosphatidylinositol 3-kinase-Akt pathway is inhibited by C2-ceramide in CAD cells. Eur J Neurosci 2007;25:3030-3038.

65 de la Monte SM: Insulin resistance and Alzheimer's disease. BMB Rep 2009;42:475-481.

66 Tong M, Neusner A, Longato L, Lawton M, Wands JR, de la Monte SM: Nitrosamine exposure causes insulin resistance diseases: relevance to type 2 diabetes mellitus, non-alcoholic steatohepatitis, and Alzheimer's disease. J Alzheimers Dis 2009;17:827-844.

67 Zhao H, Przybylska M, Wu IH, Zhang J, Siegel C, Komarnitsky S, Yew NS, Cheng SH: Inhibiting glycosphingolipid synthesis improves glycemic control and insulin sensitivity in animal models of type 2 diabetes. Diabetes 2007;56:1210-1218.

68 Zigmond E, Zangen SW, Pappo O, Sklair-Levy M, Lalazar G, Zolotaryova L, Raz I, Ilan Y: Beta-glycosphingolipids improve glucose intolerance and hepatic steatosis of the Cohen diabetic rat. Am J Physiol Endocrinol Metab 2009;296:E72-E78.

69 Holland WL, Summers SA: Sphingolipids, insulin resistance, and metabolic disease: new insights from in vivo manipulation of sphingolipid metabolism. Endocr Rev 2008;29:381-402.

70 Felder KM, Hoelzle K, Ritzmann M, Kilchling T, Schiele D, Heinritzi K, Groebel K, Hoelzle LE: Hemotrophic mycoplasmas induce programmed cell death in red blood cells. Cell Physiol Biochem 2011;27:557-564.

71 Gatidis S, Zelenak C, Fajol A, Lang E, Jilani K, Michael D, Qadri SM, Lang F: p38 MAPK Activation and Function following Osmotic Shock of Erythrocytes. Cell Physiol Biochem 2011;28:1279-1286.

72 Ghashghaeinia M, Toulany M, Saki M, Bobbala D, Fehrenbacher B, Rupec R, Rodemann HP, Ghoreschi K, Rocken M, Schaller M, Lang F, Wieder T: The NFkB Pathway Inhibitors Bay 11-7082 and Parthenolide Induce Programmed Cell Death in Anucleated Erythrocytes. Cell Physiol Biochem 2011;27:45-54.

73 Lang E, Jilani K, Zelenak C, Pasham V, Bobbala D, Qadri SM, Lang F: Stimulation of suicidal erythrocyte death by benzethonium. Cell Physiol Biochem 2011;28:347-354.

74 Nguyen DB, Wagner-Britz L, Maia S, Steffen P, Wagner C, Kaestner L, Bernhardt I: Regulation of phosphatidylserine exposure in red blood cells. Cell Physiol Biochem 2011;28:847-856.

75 Qadri SM, Kucherenko Y, Zelenak C, Jilani K, Lang E, Lang F: Dicoumarol Activates Ca-permeable Cation Channels Triggering Erythrocyte Cell Membrane Scrambling. Cell Physiol Biochem 2011;28:857-864.

76 Qadri SM, Bauer J, Zelenak C, Mahmud H, Kucherenko Y, Lee SH, Ferlinz K, Lang F: Sphingosine but not sphingosine-1-phosphate stimulates suicidal erythrocyte death. Cell Physiol Biochem 2011;28:339-346.

77 Bhavsar SK, Eberhard M, Bobbala D, Lang F: Monensin induced suicidal erythrocyte death. Cell Physiol Biochem 2010;25:745-752.

78 Braun M, Foller M, Gulbins E, Lang F: Eryptosis triggered by bismuth. Biometals 2009;22:453-460.

79 Eberhard M, Ferlinz K, Alizzi K, Cacciato PM, Faggio C, Foller M, Lang F: FTY720-induced suicidal erythrocyte death. Cell Physiol Biochem 2010;26:761-766.

80 Calderon-Salinas JV, Munoz-Reyes EG, Guerrero-Romero JF, Rodriguez-Moran M, Bracho-Riquelme RL, Carrera-Gracia MA, Quintanar-Escorza MA: Eryptosis and oxidative damage in type 2 diabetic mellitus patients with chronic kidney disease. Mol Cell Biochem 2011;

81 Nicolay JP, Schneider J, Niemoeller OM, Artunc F, Portero-Otin M, Haik G, Jr., Thornalley PJ, Schleicher E, Wieder T, Lang F: Stimulation of suicidal erythrocyte death by methylglyoxal. Cell Physiol Biochem 2006;18:223232.

82 Myssina S, Huber SM, Birka C, Lang PA, Lang KS, Friedrich B, Risler T, Wieder T, Lang F: Inhibition of erythrocyte cation channels by erythropoietin. J Am Soc Nephrol 2003;14:2750-2757.

83 Lang PA, Beringer O, Nicolay JP, Amon O, Kempe DS, Hermle T, Attanasio P, Akel A, Schafer R, Friedrich B, Risler T, Baur M, Olbricht CJ, Zimmerhackl LB, Zipfel PF, Wieder T, Lang F: Suicidal death of erythrocytes in recurrent hemolytic uremic syndrome. J Mol Med 2006;84:378-388. 
84 Kempe DS, Akel A, Lang PA, Hermle T, Biswas R, Muresanu J, Friedrich B, Dreischer P, Wolz C, Schumacher U, Peschel A, Gotz F, Doring G, Wieder T, Gulbins E, Lang F: Suicidal erythrocyte death in sepsis. J Mol Med 2007;85:273-281.

85 Lang PA, Kasinathan RS, Brand VB, Duranton C, Lang C, Koka S, Shumilina E, Kempe DS, Tanneur V, Akel A, Lang KS, Foller M, Kun JF, Kremsner PG, Wesselborg S, Laufer S, Clemen CS, Herr C, Noegel AA, Wieder T, Gulbins E, Lang F, Huber SM: Accelerated clearance of Plasmodium-infected erythrocytes in sickle cell trait and annexin-A7 deficiency. Cell Physiol Biochem 2009;24:415-428.

86 Siraskar B, Ballal A, Bobbala D, Foller M, Lang F: Effect of amphotericin B on parasitemia and survival of plasmodium berghei-infected mice. Cell Physiol Biochem 2010;26:347-354.

87 Bobbala D, Alesutan I, Foller M, Huber SM, Lang F: Effect of anandamide in Plasmodium Berghei-infected mice. Cell Physiol Biochem 2010;26:355-362.

88 Foller M, Bobbala D, Koka S, Huber SM, Gulbins E, Lang F: Suicide for survival--death of infected erythrocytes as a host mechanism to survive malaria. Cell Physiol Biochem 2009;24:133-140.

89 Koka S, Bobbala D, Lang C, Boini KM, Huber SM, Lang F: Influence of paclitaxel on parasitemia and survival of Plasmodium berghei infected mice. Cell Physiol Biochem 2009;23:191-198.

90 Kempe DS, Lang PA, Duranton C, Akel A, Lang KS, Huber SM, Wieder T, Lang F: Enhanced programmed cell death of iron-deficient erythrocytes. FASEB J 2006;20:368-370.

91 Birka C, Lang PA, Kempe DS, Hoefling L, Tanneur V, Duranton C, Nammi S, Henke G, Myssina S, Krikov M, Huber SM, Wieder T, Lang F: Enhanced susceptibility to erythrocyte "apoptosis" following phosphate depletion. Pflugers Arch 2004;448:471-477.

92 Zappulla D: Environmental stress, erythrocyte dysfunctions, inflammation, and the metabolic syndrome: adaptations to CO2 increases? J Cardiometab Syndr 2008;3:30-34.

93 Borst O, Abed M, Alesutan I, Towhid ST, Qadri SM, Foller M, Gawaz M, Lang F: Dynamic adhesion of eryptotic erythrocytes to endothelial cells via CXCL16/SR-PSOX. Am J Physiol Cell Physiol 2011;

94 Andrews DA, Low PS: Role of red blood cells in thrombosis. Curr Opin Hematol 1999;6:76-82.

95 Closse C, Dachary-Prigent J, Boisseau MR: Phosphatidylserine-related adhesion of human erythrocytes to vascular endothelium. Br J Haematol 1999;107:300-302.

96 Gallagher PG, Chang SH, Rettig MP, Neely JE, Hillery CA, Smith BD, Low PS: Altered erythrocyte endothelial adherence and membrane phospholipid asymmetry in hereditary hydrocytosis. Blood 2003;101:46254627.

97 Pandolfi A, Di Pietro N, Sirolli V, Giardinelli A, Di Silvestre S, Amoroso L, Di Tomo P, Capani F, Consoli A, Bonomini M: Mechanisms of uremic erythrocyte-induced adhesion of human monocytes to cultured endothelial cells. J Cell Physiol 2007;213:699-709.

98 Wood BL, Gibson DF, Tait JF: Increased erythrocyte phosphatidylserine exposure in sickle cell disease: flowcytometric measurement and clinical associations. Blood 1996;88:1873-1880.

99 Chung SM, Bae ON, Lim KM, Noh JY, Lee MY, Jung YS, Chung JH: Lysophosphatidic acid induces thrombogenic activity through phosphatidylserine exposure and procoagulant microvesicle generation in human erythrocytes. Arterioscler Thromb Vasc Biol 2007;27:414-421.

100 Zwaal RF, Comfurius P, Bevers EM: Surface exposure of phosphatidylserine in pathological cells. Cell Mol Life Sci 2005;62:971-988. 